Armour-Brown, A., Tukiainen, T. \& Wallin, B. 1982: The South Greenland uranium exploration programme. Final Report of reconnaissance results. Unpubl. intern. GGU rep., 95 pp.

Armour-Brown, A., Tukiainen, T., Wallin, B., Bradshaw, C. \& Emeleus, C. H. 1983: Uranium exploration in South Greenland. Rapp. Grønlands geol. Unders. 115, 68-75.

Armour-Brown, A., Tukiainen, T., Nyegaard, P. \& Wallin, B. 1984: The South Greenland regional uranium exploration programme. Final report of progress 1980-1983. Unpubl. intern. GGU rep., 107 pp.

Emeleus, C. H. \& Upton B. G. J. 1976: The Gardar period in southern Greenland. In Escher, A. \& Watt, W. S. (edit.) Geology of Greenland, 154-181. Copenhagen: Geol. Surv. Greenland.

Emeleus, C. H. \& Stephenson, D. 1970: Field work between Tunugdliarfik and Tasiussaq. Rapp. Grønlands geol. Unders: 28, 30-32.

Hansen, J. 1968: A study of radioactive veins containing rare-earth minerals in the area surrounding the Ilimaussaq alkaline intrusion in South Greenland. Bull. Grønlands geol. Unders. 76 (also Meddr Grønland 181,8) $47 \mathrm{pp}$.

Poulsen, V. 1964: The sandstones of the Precambrian Eriksfjord Formation in South Greenland. Rapp. Gronlands geol. Unders. 2, $16 \mathrm{pp}$.

Van Breemen, O., Aftalion, M. \& Allaart, J. H. 1974: Isotopic and geochronologic studies on granites from the Ketilidian mobile belt of South Greenland. Bull. geol. Soc. Amer. 85, 403-412.

\title{
Geophysical field work in relation to mineral exploration programmes in South Greenland
}

\section{Thorning and M. Boserup}

Geophysical field work in connection with mineral exploration programmes was carried out in two areas in South Greenland: on the Narssaq peninsula south-west of Qagssiarssuk in co-operation with P. Nyegaard and A. Armour-Brown (Sydex project), and north of Motzfeldt Sø in co-operation with T. Tukiainen (Niobium project). This note briefly describes the objectives of the field work and gives examples of the data acquired from one area.

The field activities were supported logistically from GGU's facilities in Narssarssuaq (J. Lau), and were carried out from tent camps in the two areas. Camps were moved by S-61 helicopter. Besides the authors, Egon Hansen (electronics technician) and Jette Halskov (assistant) participated in the field work which took place from June 27th to August 27th. The summer was characterized by frequent bad weather including storms and snow and, consequently, data coverage is not as complete as had been hoped. The main objectives of the field work, however, were achieved.

There were several innovations in this summer's instrumentation (see later) and equipment. The use of two new tents (Hansen Weatherport, insulated) for the mess and 'geophysical' huts made it possible to endure the hardships of long periods of bad weather and to make the geophysical equipment usable in sub-zero temperatures, fog and other types of adverse weather. These gains easily outbalance the slightly added total weight of the camp. 


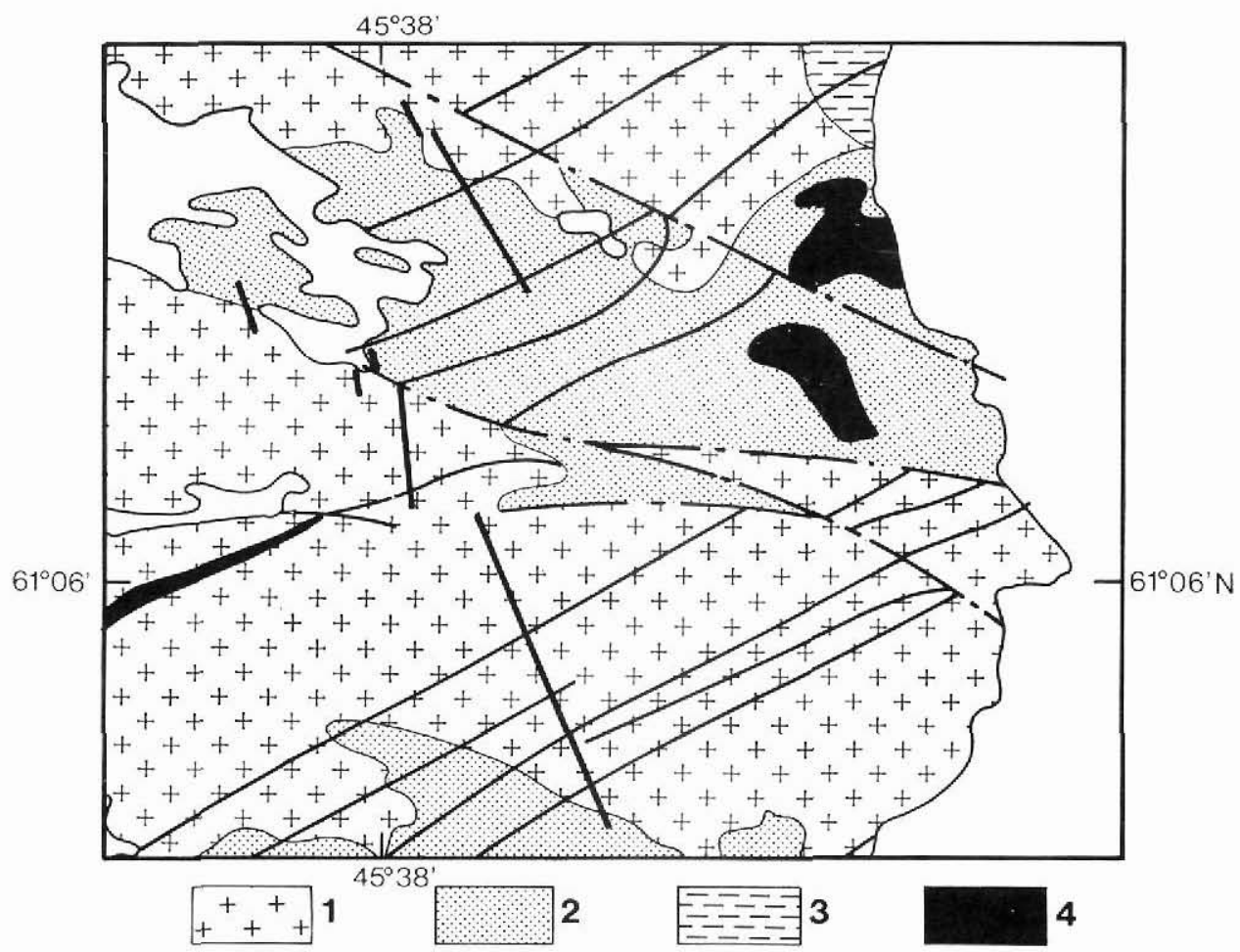

Fig. 26. Regional geophysical profiles (magnetic and VLF) on the Narssaq peninsula, South Greenland, 1984. 1: Julianehåb granite, 2: Sandstone, 3: Gneiss, 4: Carbonatite.

\section{Instrumentation and methods}

A magnetic survey and a VLF profiling survey were carried out with supporting measurements of magnetic susceptibility and electric resistivity.

In the Qagssiarssuk area, ten lines of varying length were laid out perpendicular to main geological boundaries between the Eriksfjord Formation and the Julianehåb Granite in the area. In the Motzfeldt area, the profiles were placed in a regular grid with $40 \mathrm{~m}$ spacing between profiles. The orientation of the profiles was approximately perpendicular to the direction to the VLF station NAA at Cutler, Maine. The distance between measurements along the lines was $10 \mathrm{~m}$. A theodolite was used for laying out the lines, but precise triangulation was not attempted.

The field instruments used were a Geometrics G856 proton precession magnetometer, a newly acquired Scintrex IGS-2/VLF4 receiver, and two Scintrex SM5 susceptibility meters. Magnetic base measurements were made at the camp site by a Geometrics G803 proton precession magnetometer using a Hewlett-Packard HP85 personal computer as a data-logger. For the first time all field data were read onto tape cassettes on the HP85, and this was used for a number of calculations in the field including diurnal correction of the magnetic data, filtering of VLF data by the methods of Fraser (1969) and Karous \& Hjelt (1983), printing and plotting of data etc, using programs of Leff (1982) and programs developed by one of the au- 


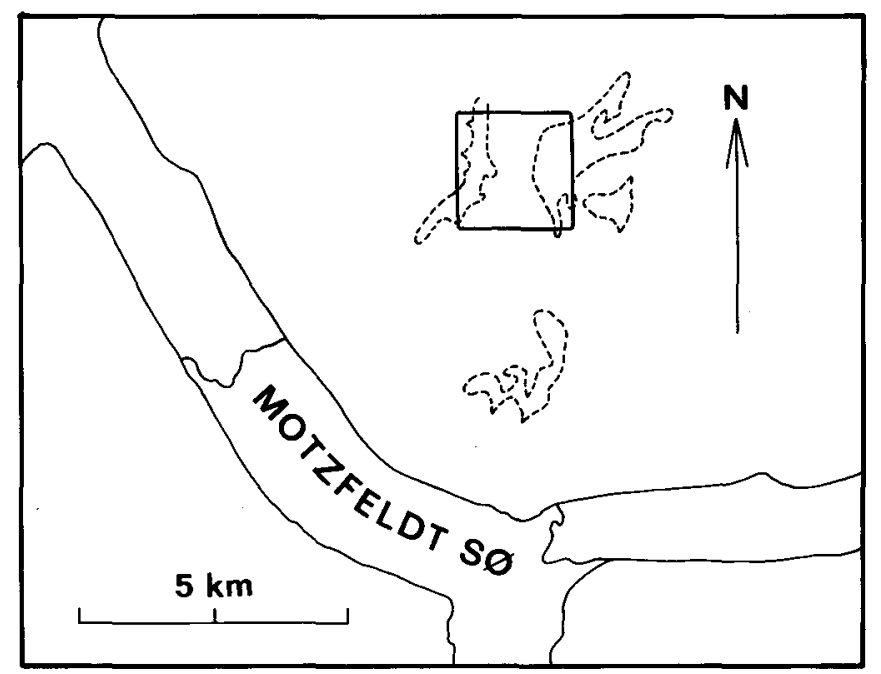

Fig. 27. Field area for geophysical work at Motzfeldt $\$ \varnothing 1984$.

thors (LT). Power was supplied by lead batteries charged by a Bosch G2400 220V AC generator. All VLF profiles were measured using the NAA station $(24.0 \mathrm{kHz})$, the transmitter with the strongest signal in the survey area. The GBR station at Rugby, England $(16.0 \mathrm{kHz})$ was used on some of the profiles. Other stations were tried at the start of the field season, but abandoned, because the signal was too weak or of too variable strength.

Measurements of electric resistivity were carried out at selected localities in the Qagssiarssuk area using the Scintrex VLF4 in the E-field mode. The field area at Motzfeldt Sø was unsuitable for such measurements. When possible, magnetic susceptibilities were measured at sites along profiles so that all rock types encountered in the Qagssiarssuk area were represented and correlated directly to geological observations (Nyegaard, this report).

\section{Regional profiles near Qagssiarssuk, Narssaq peninsula}

In 1982 geophysical field work at Puissagtaq near Igaliko established that the major eastwest fault structures, as well as secondary structures related to the movements along the main trends, can be revealed and mapped by a combination of VLF and magnetic surveys (Nyegaard \& Thorning, 1983; Armour-Brown et al., 1984). Similar structures were expected on the Narssaq peninsula south-west of Qagssiarssuk, an area further complicated by the presence of both lavas and sandstones of the Eriksfjord Formation and many types of mainly SW-NE striking dykes. Uranium mineralization is related to these structures (ArmourBrown et al., 1984). In order to obtain a better indication of how the structures of the Narssaq peninsula affect magnetic and VLF surveys, several profiles were measured in an approximately north-south direction crossing main east-west fault zones and several boundaries between the Eriksfjord Formation and the Julianehåb Granite (fig. 26). A total of 10.6 $\mathrm{km}$ of profile were measured. No data will be presented here, but some observations made in the field are briefly summarized. 

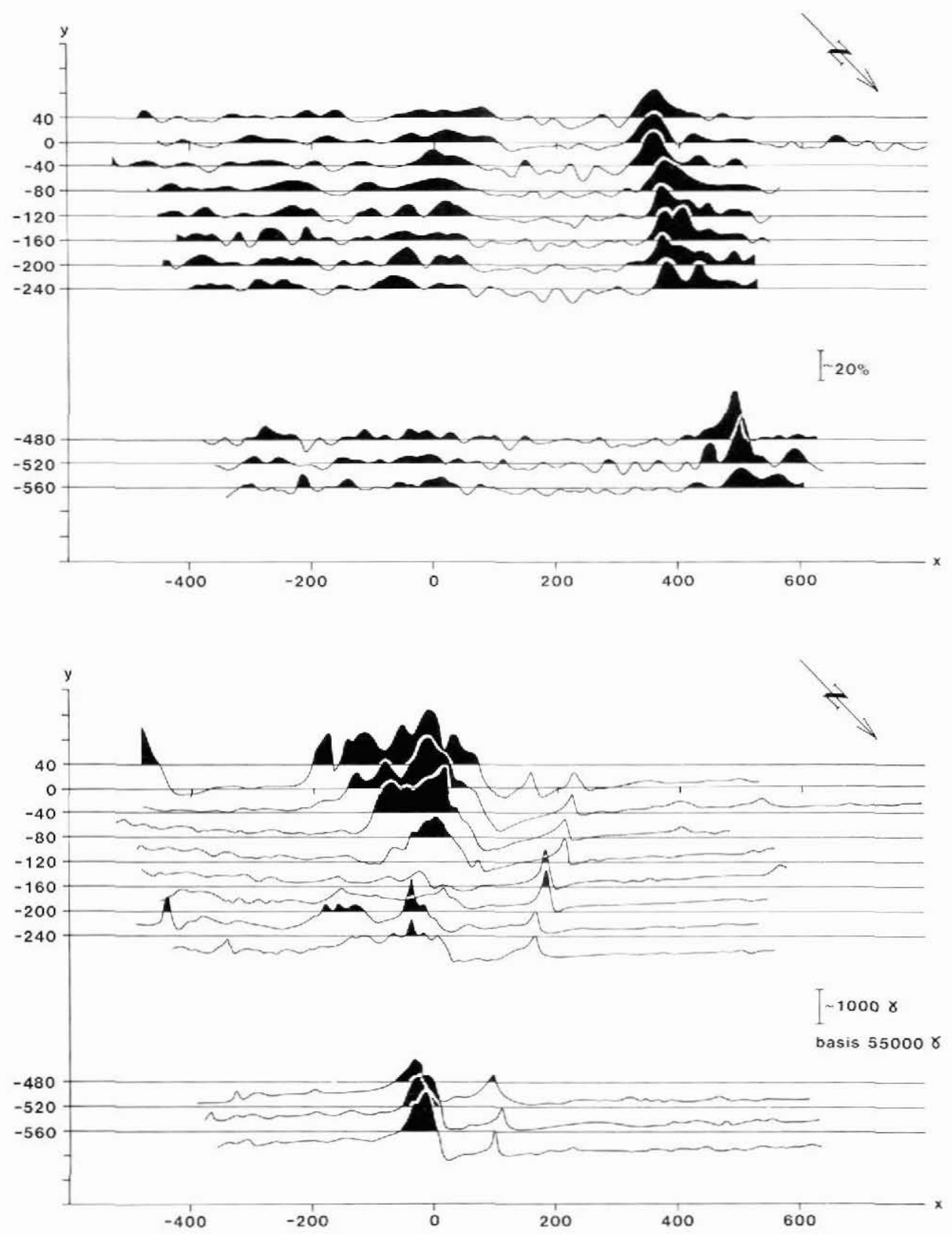

Fig. 28. Examples of magnetic and VLF data from the Motzfeldt Centre. (b) Magnetic total field data. (a) Fraser-filtered VLF inphase data. 
Several fault zones were apparent in both the magnetic and the VLF data, e.g. in the valley between Nunâtâk and Ingnerûlalik. Similar structures were observed in the Puissagtaq area (Nyegaard \& Thorning, 1983). The various types of dykes could be partly separated through their magnetic anomalies, and at least two varieties of the (fresh) Julianehåb Granite could be distinguished. Future work on the geophysical data will include detailed correlation with geological features and modelling of selected structures, e.g. fault zones and contact between the Eriksfjord Formation and the granite. The data will serve as a basis for planning of airborne surveys and could provide ground control for the interpretation of such surveys.

\section{Detailed survey at Motzfeldt $S \varnothing$}

Earlier work by Tukiainen et al. (1984), Armour-Brown et al. (1984) and others has shown that the Motzfeldt Centre of the Igaliko Complex has a significant economic mineral potential. It was decided to carry out a detailed geophysical survey over a badly exposed area on the high plateau north of Motzfeldt Sø (fig. 27), where several linear features may carry a sulphide mineralization genetically related to the Motzfeldt intrusion. A total of $17.2 \mathrm{~km}$ of VLF and magnetic data were acquired in a regular grid with NE-SE striking profiles.

Eight profiles are shown in fig. 28. The magnetic field is dominated by high amplitude magnetic anomalies associated with a basalt breccia of the Eriksfjord Formation and a linear anomaly which is probably related to a Gardar dyke. The Fraser-filtered VLF inphase data show two major linear anomalies which are probably related to mineralized faults. Linear filtering of the VLF data according to Karous \& Hjelt (1983), carried out in the field, indicate that these conductors extend in depth to at least 50-60 metres. It is interesting that no magnetic anomalies are associated with the linear VLF anomaly, which is best seen at the northernmost anomaly: this is apparently not the same type of fault structure as those investigated at Puissagtaq and Qagssiarssuk. Field observations by Tukiainen et al. (this report) indicate that the source of the VLF anomalies may be a sulphide mineralization. Plans for future work include modelling of geological structures and calculation of the topographic effect on the VLF data because the conductors partly coincide with small ridges, and there is thus a risk that part of the VLF anomalies may be caused by the topography. A series of geophysical maps will also be produced.

Acknowledgements. We would like to thank $\mathbf{J}$. Lau for his great support as base camp manager in Narssarssuaq, E. Hansen and $J$. Halskov for their valuable contributions to the field work, and geologists $T$. Tukiainen, P. Nyegaard and A. Armour-Brown for useful and enjoyable co-operation in the field.

\section{References}

Armour-Brown, A., Tukiainen, T., Nyegaard, P. \& Wallin, B. 1984: The South Greenland regional uranium exploration programme. Final report of progress 1980-1983. Unpubl. intern. GGU rep., 107 pp.

Fraser, D. C. 1969: Contouring of VLF-EM data. Geophysics 34, 958-967.

Karous, M. \& Hjelt, S. E. 1983: Linear filtering of VLF dip-angle Measurements. Geophysical Prospecting 31, 782-794. 
Leff, B. J. 1982: Application note - the HP85 Personal Computer and the G856 'Memory Mag (TH)'. EG \& G Geometrix, Inc., 48 pp.

Nyegaard, P. \& Thorning, L. 1983: Geophysical and geological field work on fault structures at the Igaliko peninsula, South Greenland. Rapp. Grønlands geol. Unders. 119, 75-79.

Tukiainen, T., Bradshaw, C. \& Emeleus, C.H. 1984: Geological and radiometric mapping of the Motzfeldt Centre of the Igaliko Complex, South Greenland. Rapp. Grønlands geol. Unders. 120, 78-83.

\section{Greenland ice cap aeromagnetic survey 1984: reconnaissance lines in southern Greenland}

\section{Thorning, M. Bower, C. D. Hardwick and P. J. Hood}

No large-scale systematic operations over the Greenland ice cap were planned for 1984 . However, in April 1984 the possibility arose of obtaining data along some reconnaissance lines in South Greenland, using the same aircraft and instrumentation as in 1983 (Thorning et al., 1984). From bases at Keflavik in Iceland, and Søndre Strømfjord and Narssarssuaq in Greenland, four lines were flown in South Greenland, starting over the ice cap near Ivigtut and extending well offshore south-east of Kap Farvel (fig. 29). A long offshore tie-line was flown from the Denmark Strait around the south tip of Greenland and into the Davis Strait joining the tie-line flown there in 1983 (Thorning et al., 1984). A planned flight line, starting well offshore south of Greenland and following the eastern rim of the ice cap north to the survey area of the 1983 operations (Thorning et al., 1984) had to be abandoned because one engine of the Convair 580 developed a problem which effectively closed down further operations on this occasion.

The purpose of the reconnaissance lines was to evaluate the magnetic effect of major geological boundaries in South Greenland: the Ketilidian-Archaean boundary, the granite

Fig. 29. Approximate position of four reconnaissance lines over South Greenland. Length of each profile $c .400 \mathrm{~km}$. Distance between profiles c. $5 \mathrm{~km}$. Altitude varies, but is $1000 \mathrm{ft}$. over the ice cap and offshore.

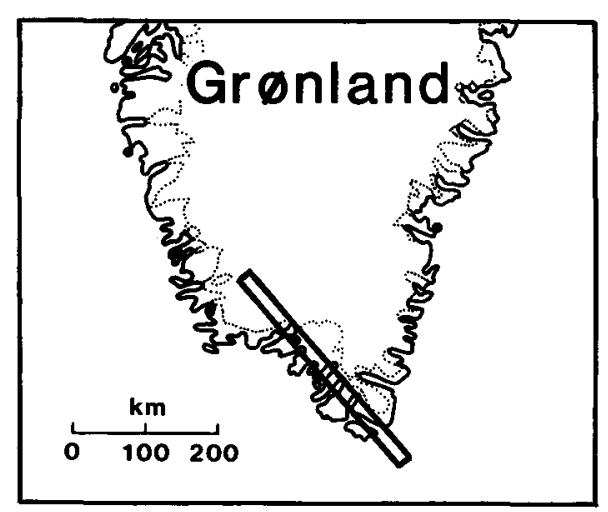

